Artículo científico

(Original paper)

\title{
ADAPTABILITY OF THE THREATENED JAGUARUNDI (HERPAILURUS YAGOUAROUNDI SCHREBER, 1777) TO HUMAN-ALTERED ENVIRONMENTS IN SAN LUIS POTOSÍ, MEXICO
}

\section{ADAPTABILIDAD DEL AMENAZADO JAGUARUNDI (HERPAILURUS YAGOUAROUNDI SCHREBER, 1777) A AMBIENTES ANTROPIZADOS EN SAN LUIS POTOSÍ, MÉXICO}

\author{
WENDY PAOLA CORONADO-QUIBRERA ${ }^{1}$, GENARO OLMOS-OROPEZA ${ }^{2}$, LOUIS C. BENDER ${ }^{3}$, OCTAVIO \\ CÉSAR ROSAS-ROSAS ${ }^{2 *}$, Jorge PALACIO-NÚÑEZ², LuIS ANTONIO TARANGO-ARÁMBULA ${ }^{2}$, José G. \\ HERRERA-HARO ${ }^{1}$ \\ ${ }^{1}$ Colegio de Postgraduados. Carretera Federal México-Texcoco, Km 36.5, Montecillo, Texcoco, 56230, Edo. de México. \\ <wendyspookie@hotmail.com>; <haro@colpos.mx> \\ ${ }^{2}$ Colegio de Postgraduados Campus San Luis Potosí. Iturbide 73, Salinas de Hidalgo, San Luis Potosí. 78600, México. \\ <olmosg@colpos.mx>; <octaviocrr@colpos.mx>; <jpalacio@colpos.mx>; <ltarango@colpos.mx> \\ ${ }^{3}$ Extension Animal Sciences and Natural Resources, PO Box 30003 MSC 3AE, New Mexico State University, Las Cruces, NM \\ 88011, USA. <lbender@nmsu.edu> \\ *Autor de correspondencia: <octaviocrr@colpos.mx>
}

Recibido: 27/05/2019; aceptado: 14/10/2019; publicado en línea: 21/10/2019

Editor responsable: Sonia Gallina

Coronado-Quibrera, W. P., Olmos-Oropeza, G., Bender, L. C., Rosas-Rosas, O. C., Palacio-Núñez, J., Tarango-Arámbula, L. A., Herrera-Haro, J. G. (2019) Adaptability of the threatened jaguarundi (Herpailurus yagouaroundi Schereber, 1777) to human-altered environments in San Luis Potosí, Mexico. Acta Zoológica Mexicana (nueva serie), 35, 1-15. https://doi.org/10.21829/azm.2019.3502210

\begin{abstract}
Persistence and recovery of rare species in developing regions with limited protected areas depends upon their adaptability to human-altered habitats. The jaguarundi (Herpailurus yagouaroundi) is classed as threatened in Mexico, and knowledge of its distribution and environmental correlates is necessary for informed recovery efforts. However, little is known of jaguarundi habitat or distribution in interior Mexico, including the state of San Luis Potosí (SLP). We conducted 96 semi-structured interviews around communities, ejidos, and ranches throughout SLP to obtain records of jaguarundi presence and identify environmental correlates and site attributes associated with its occurrence. We evaluated interviews using analytical criteria of credibility, and collected habitat information from 50 reliable occurrences from three of the four geographic regions of SLP. Compared to the SLP landscape, jaguarundi occurrences were located closer to water, closer to roads, at lower elevation, marginally closer to communities, and in areas with greater total edge, edge density, and number of landscape patches. Jaguarundi showed preference for mosaics of tropical forest, agricultural, grassland, and urban (i.e., any community) cover types. Relatively dense hiding or ambush cover was usually present at occurrence sites. Collectively, maximum entropy modeling and logistic regression modeling predicted similar and high likelihood of jaguarundi presence in regions characterized by mosaics of tropical forest, agriculture, grassland, or urban cover types $<500 \mathrm{~m}$ in elevation and $<2 \mathrm{~km}$ from roads. These mosaic landscapes tended to be relatively close to communities of moderate population densities and water, and typically support higher small prey densities than less
\end{abstract}


fragmented areas. Jaguarundi were adaptable to at least light-moderate human-related disturbance, and may be benefitted by it because of increased edge and habitat mosaics.

Key words: Distribution; habitat; Herpailurus yagouaroundi; jaguarundi; Mexico

Coronado-Quibrera, W. P., Olmos-Oropeza, G., Bender, L. C., Rosas-Rosas, O. C., Palacio-Núñez, J., Tarango-Arámbula, L. A., Herrera-Haro, J. G. (2019) Adaptabilidad del amenazado jaguarundi (Herpailurus yagouaroundi Schreber, 1777) a ambientes antropizados en San Luis Potosí, México. Acta Zoológica Mexicana (nueva serie), 35, 1-15. https://doi.org/10.21829/azm.2019.3502210

RESUMEN. La persistencia y recuperación de especies raras en regiones en desarrollo con áreas protegidas limitadas depende de su adaptabilidad a los hábitats alterados por el hombre. El jaguarundi (Herpailurus yagouaroundi) está clasificado como amenazado en México, y el conocimiento de su distribución y su correlación con el ambiente es necesario para los esfuerzos de recuperación informados. Sin embargo, poco se sabe sobre el hábitat o la distribución de jaguarundi en el interior de México, incluido el estado de San Luis Potosí (SLP). Realizamos 96 entrevistas semiestructuradas en comunidades, ejidos y ranchos a lo largo de SLP para obtener registros de la presencia de jaguarundi e identificar correlaciones ambientales y atributos de sitios asociados con su ocurrencia. Evaluamos las entrevistas utilizando criterios analíticos de credibilidad y recopilamos información sobre hábitats de 50 eventos confiables de tres de las cuatro regiones geográficas de SLP. En comparación con el paisaje de SLP, las ocurrencias de jaguarundi se ubicaron más cerca del agua, más cerca de las carreteras, a bajas elevaciones, marginalmente más cerca de las comunidades, y en áreas con mayor borde total, densidad de bordes y número de parches de paisaje. El jaguarundi mostró preferencia por los mosaicos de bosques tropicales, agrícolas, de pastizales y urbanos (es decir, cualquier comunidad). Coberturas de escondite relativamente denso o de emboscada generalmente estaban presentes en los sitios de ocurrencia. Colectivamente, el modelo de máxima entropía y el modelo de regresión logística predijeron una probabilidad similar y alta de presencia de jaguarundi en regiones caracterizadas por mosaicos de bosques tropicales, agricultura, pastizales o tipos de cobertura urbana $<500$ $\mathrm{m}$ en elevación y $<2 \mathrm{~km}$ desde carreteras. Estos paisajes de mosaicos tendían a estar relativamente cerca de comunidades de densidades moderadas de población y agua, y generalmente soportan densidades de presas pequeñas más altas que las áreas menos fragmentadas. Los jaguarundi se adaptaron al menos a las perturbaciones ligeras y moderadas relacionadas con los seres humanos, y pueden verse beneficiados por el aumento de los mosaicos de borde y hábitat.

Palabras clave: Distribución; hábitat; Herpailurus yagouaroundi; jaguarundi; México

\section{INTRODUCTION}

The jaguarundi (Herpailurus yagouaroundi) is a threatened species in Mexico (NOM-059; SEMARNAT, 2010) and is listed under Appendix I of CITES (Caso et al., 2015). While widely distributed along the Pacific and Gulf coasts (Leopold, 1959; de Oliviera, 1998; Aranda, 2005), much less is known of its distribution in interior Mexico including the state of San Luis Potosí (SLP), and it remains the least studied felid in Mexico. San Luis Potosí hosts a wealth of ecosystems and biodiversity due to high floristic diversity associated with its geographic location in the Nearctic-Neotropical zoogeographical transitional region, rugged topography, and climatic complexity (Escalante et al., 2005). Despite this diversity, historically there were only three visual records of jaguarundi from SLP (Dalquest, 1953; Leopold, 1959). However, recent observations of jaguarundi in SLP (Méndez-Salinas, 2009; Villordo-Galván et al., 2010; HernándezSaintMartín et al., 2013; Benítez-Alemán, 2014) indicate presence in some areas, although the overall distribution of jaguarundi and its habitat associations in SLP remain uncertain. 
Establishment of protected areas is commonly espoused as a practical method of conserving natural communities including habitats preferred by rare species (Primack, 1993; Ochoa-Ochoa et al., 2009). However, only $1.6 \%$ of SLP is protected at the Federal level and 6.6\% at the State level (Chapa-Vargas \& Monzalvo-Santos, 2012), well below recommendations of 12-18\%. Additionally, many natural communities in SLP face continued alteration due to a variety of human-related activities, including logging, conversion to agriculture, growth of communities, and livestock grazing (INEGI, 2002; Chapa-Vargas \& Monzalvo-Santos, 2012). Because of this, and despite being less impacted by human development than many other areas of Mexico, many areas of SLP lost $40 \%$ to nearly $100 \%$ of natural communities between 1966 and 2000 (Huber-Sannwald, 2002; INEGI, 2002; Chapa-Vargas \& Monzalvo-Santos, 2012). Hence, protected areas alone are unlikely to provide a suitable long-term solution to conserving jaguarundi.

Thus, a key to the long-term viability of jaguarundi is their adaptability to human-induced changes in natural communities, particularly tolerance of human-related development. Despite this, presence of jaguarundi in human-altered environments, and attributes that may facilitate that presence in SLP, are unknown. Unlike many rare felids, however, jaguarundi are apparently adaptable to a variety of habitat types (Aranda, 2005; Charré-Medellín et al., 2012; Caso, 2013; Farías et al., 2015; Giordano, 2016), may be tolerant of habitat disturbance (de Oliviera, 1998; Carrillo et al., 1999; Caso et al., 2005; Giordano, 2016), and may prefer edge habitats (Cabrera \& Yepes, 1960; Caso, 2013; Giordano, 2016). Thus, the highly diverse landscape of SLP potentially provides suitable habitat conditions, including areas with humanrelated development and fragmentation, such as rural communities, agricultural, and agroforestry environments.

Knowledge of the distribution and environmental attributes associated with the presence of speciesof-concern is fundamental to the development of informed recovery plans. Consequently, because the overall distribution of jaguarundi, and the adaptability of jaguarundi for human-altered habitats in SLP is uncertain, our goal was to determine the current distribution of jaguarundi in SLP and to characterize both landscape-level and site-level environmental features that may facilitate its presence in light-moderately human-altered environments, such as rural communities, ejidos, ranches, and other agricultural landscapes.

\section{MATERIALS AND METHODS}

Study area. The state of SLP (Fig. 1) is located in east-central Mexico, between $21^{\circ} 10^{\prime}-24^{\circ} 29^{\prime} \mathrm{N}$ and $98^{\circ}$ $20^{\prime}-102^{\circ} 18^{\prime} \mathrm{W}$ (INEGI, 2002). San Luis Potosí has a great diversity of vegetation types, including piedmont scrub, scrubland, and grassland, as well as temperate (oak [Quercus spp.], pine [Pinus spp.]-oak, and cloud forests) and tropical-subtropical forests (Rzedowski, 1966). Four geographic regions are identified: Altiplano, Zona Media, Zona Centro and Huasteca Potosina (Fig. 1). Climates included dry and semi-dry (74\% of the State), semi-warm (16\%), warm (8\%), and temperate (2\%). Agriculture and cattle ranching are among the most important economic activities (INEGI, 2002).

Jaguarundi occurrences. We obtained field records of jaguarundi occurrences following the methodology of de Oliveira (1994). Because we were primarily interested in presence in or near human-altered habitats, we conducted during October 2008-May 2009 interviews in and around 96 rural communities (mean population $=778$ [range $=10-10,562]$; excluding the six largest communities with $>1,000$ residents each, mean population $=296$ [range $=10-975]$ ), ejidos, and ranches within the four geographic regions of SLP. Around each area, we interviewed local residents who were familiar with the local fauna, including hunters, rural authorities, livestock producers, and farmers. For each interview we recorded the type of evidence indicating presence of jaguarundi (e.g., road kill, sighting, skins, skulls, etc.), approximate date of sighting, and place of sighting. We also evaluated the knowledge of the person interviewed regarding jaguarundi by showing a series of images of different felids and determining their ability to recognize jaguarundi (Rabinowitz, 1993). 
We classed the combined information from the interview and the images by its reliability using the analytical criterion of Tewes and Everett (1986) following several other studies of cryptic felids (e.g., Shindle \& Tewes, 1998; Grigione et al., 2007; Horne et al., 2009; Villordo-Galván et al., 2010; MartínezCalderas et al., 2011). These criteria classes included: Class I, where observations were made by a reliable and experienced observer and supported by physical evidence; Class II, where a detailed description was provided by a reliable and experienced observer; and Class III, where details provided by the observer were vague and not specific (Tewes \& Everett, 1986).

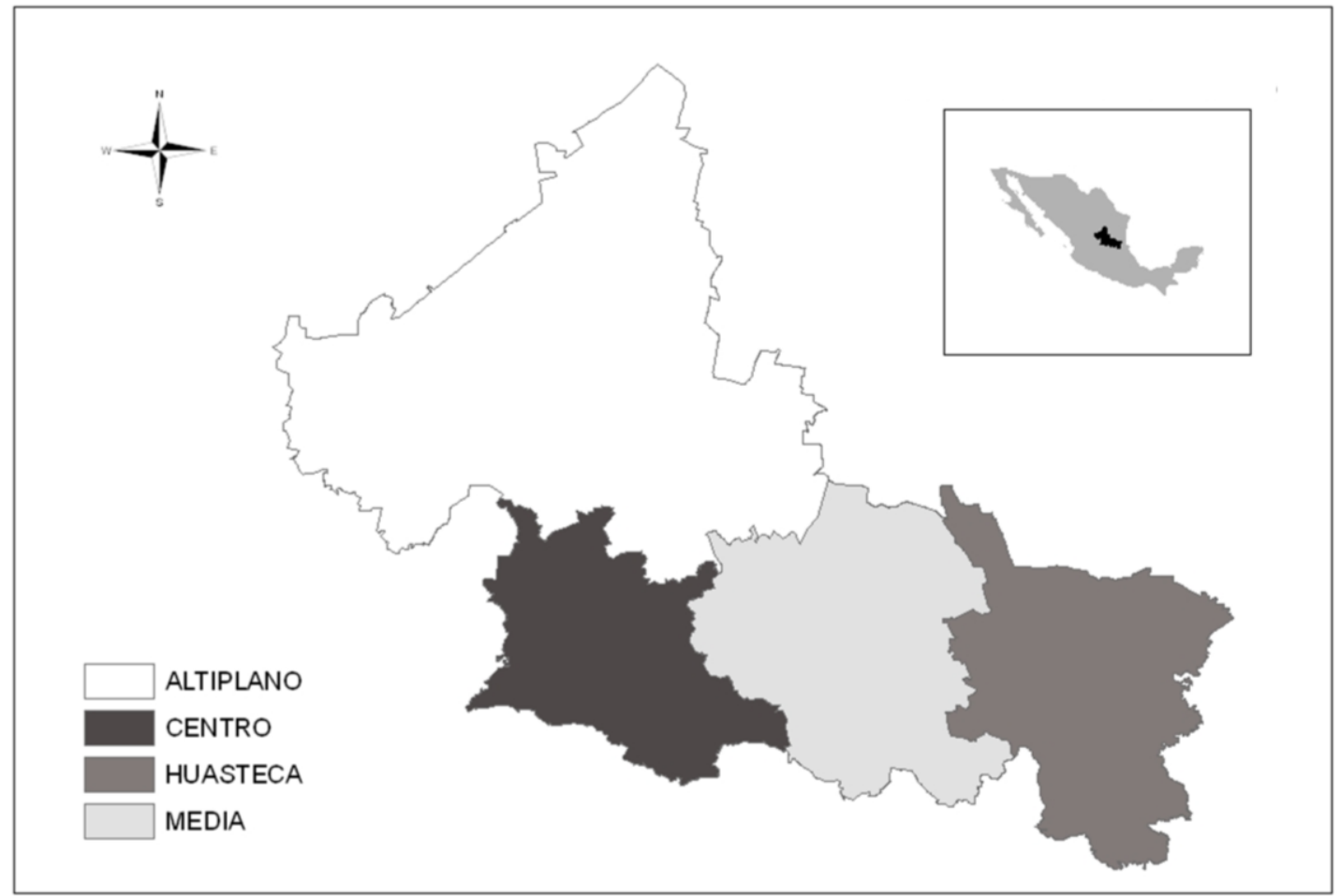

Figure 1. Location of San Luis Potosí in Mexico and its four geographic regions: Altiplano, Zona Media, Zona Centro and Huasteca Potosina.

Environmental correlates. We located and geo-referenced each record of jaguarundi using a Global Positioning System receiver. We used or created digital maps (INEGI, 2002, 2013) in ArcMap 10.1 (ESRI; Redlands, California, USA) to determine environmental variables associated with jaguarundi occurrences. These variables included (1) vegetation cover type; (2) distance to the nearest water source; (3) distance to the nearest community; (4) distance to paved and unimproved roads; (5) elevation; and (6) human population density. We selected these variables because they have previously been shown to be important for habitat evaluations of other felid species (e.g., Carrol \& Miquelle, 2006; Martínez-Calderas, 2009) and several specifically addressed associations with human-altered habitats, as well as characteristics of human-altered habitats that could be contrasted with the overall SLP landscape.

We also determined several patch and edge related statistics (Patch Analyst 5.2; Rempel et al., 2012), including total number of patches, patch density, total amount of edge, edge density, patch relative density, and relative patch richness, to assess if jaguarundi presence was associated with more or less fragmented habitats. We used a $2.5-\mathrm{km}$ radius circular plot centered on jaguarundi locations and random points to calculate these statistics, which corresponded to male jaguarundi home range size in northeastern Mexico (Caso, 2013). We generated 10,000 random points across SLP and extracted these same variables for each random point. We then compared jaguarundi locations and random points for the continuous 
variables using MANOVA (Morrison, 1990) and for cover type using Fisher's exact test (Zar, 1996) to contrast habitat correlates of jaguarundi from rural survey areas with the SLP landscape.

Landscape modeling. We constructed models of habitat correlates of jaguarundi presence using both logistic regression (Zar, 1996) and maximum entropy modeling (Maximum Entropy 3.1 [MaxEnt]; Phillips et al., 2006) to identify the environmental variables associated with jaguarundi presence in our surveyed areas (Trisurat \& Bhumpakphan, 2018). We used the environmental variables noted above for distribution modeling. For logistical models, we modeled all possible additive candidate models, and used stepwise logistic regression to identify the environmental variables most associated with jaguarundi presence. We used stepwise regression because it is more conservative than information-theoretic model selection methods (Arnold, 2010).

For maximum entropy modeling, we modeled all possible candidate models using the complementary log-log (clog-log) transformation. We compared models by testing whether the model with the highest area-under-curve (AUC; Swets, 1988) differed from more parsimonious models. We used the critical ratio test (Pearce \& Ferrier, 2000 as modified by Baldwin \& Bender, 2008) to compare the highest AUC model with other models to determine if the increase in explanatory value was significant at $\alpha=0.05$ following Baldwin \& Bender (2008). If models did not differ, we selected the most parsimonious model. We calculated standard errors for AUC values using $30 \%$ of the locations as test data. We derived thresholds for probability of jaguarundi presence by maximizing sensitivity and minimizing specificity (Fielding \& Bell, 1997; Phillips et al., 2006). We used these thresholds to convert probabilities to binary response (presence-absence) and used the equal test sensitivity and specificity threshold values to calculate successful classification percentages. Last, we compared the final model to 1,000 random null models following Raes $\&$ ter Steege (2007) and determined the probability that the fit (AUC) of the final model was greater than the AUC of the random models.

Because fine resolution cover type maps may poorly reflect interspersion or mosaics of cover types as compared to coarser resolution cover type maps that include mosaic habitats in cover type designations (e.g., 300-m resolution maps such as GlobCover [2008]), we also assessed whether cover types in preferred logistic and maximum entropy models were more indicative of uniform or mosaic patches. For this, we created a 300-m resolution window around jaguarundi occurrences and random points and extracted the fine resolution cover types (from the 30-m resolution raster used in modeling; INEGI, 2013) within this neighborhood. We then determined whether the fine resolution cover type at the sample point was the predominant cover type in the neighborhood and identified which other cover types, if any, were present in the neighborhood. We considered the neighborhood essentially a uniform cover type if $\geq 90 \%$ of the $30-\mathrm{m}$ pixels were of the same cover type, and defined mosaics by the two predominant cover types if no single cover type comprised $\geq 90 \%$ of the pixels.

Last, we compared final logistical and maximum entropy models using AUC and successful classification outcomes (Trisurat \& Bhumpakphan, 2018) but using parametric bootstrapping and contingency tables, respectively (Efron \& Tibshirani, 1993; Zar, 1996). We included the latter because a model that poorly classifies the data it was built from is unlikely to have any true predictive ability (Hosmer \& Lemeshow, 1989). We also compared similarity of model predictions (i.e., predicted likelihood of jaguarundi presence) using Warren's I statistic (Warren et al., 2008) at $\mathrm{N}=10,000$ random locations.

Site characteristics. At each occurrence we recorded site-level descriptive variables including (1) actual vegetation cover type at the occurrence site (as opposed to mapped cover type); (2) predominant vegetation cover type seen in the surrounding area of the site of occurrence (i.e., aspect dominant cover type); (3) percent ambush cover; and (4) degree of habitat disturbance. We defined ambush cover as the estimated proportion of an individual jaguarundi detectible through the vegetation when recumbent (lying down) as if waiting for prey or hiding from predators. We estimated this variable using a $1.5 \times 0.6 \mathrm{~m}$ screen placed at 
the location of the jaguarundi sighting and $0.5 \mathrm{~m}$ above the ground. We recorded the percent of the screen obscured by vegetation from each of the four cardinal directions at five meters and used the mean as our estimate of ambush cover (Tewes \& Schmidly, 1987; Griffith \& Youtie, 1988; Dillon, 2005). We then classified ambush cover as high (76-100\%), medium (51-75\%), low (26-50\%), and very low (0-25\%). We also estimated the degree of disturbance to the habitat following the criteria of Martínez-Calderas (2009). We classed disturbance as high, medium, or low according to the presence of secondary vegetation, grazing (defined in terms of tracks, feces, and livestock presence), agricultural fields, and habitat clearings. We compared ambush cover and disturbance among classes using Fisher's exact test (Zar, 1996). We compared cover types at sites of locations with the SLP landscape as described above.

\section{RESULTS}

Environmental correlates. We documented 50 reliable records (five Class I and 45 Class II) of jaguarundi around primarily rural communities (but including communities of $>10,000$ residents), ejidos, and ranches (Table 1). Date of records ranged from 2002-2008. We confirmed the presence of jaguarundi in Zona Huasteca (33), Zona Media (14) and Zona Centro (3) of SLP, but not the Altiplano region. Cover types at the location of occurrences included rainfed and irrigated agriculture $(n=14)$; tropical forest (including tall evergreen tropical forest, subperennifolious tropical forest, and lowland deciduous forest; $n=10$ ); scrub (including submontane scrub, microphyle desert scrub, and succulent-rosette scrub; $n=10$ ); natural and cultivated grassland $(n=9)$; temperate forest (including oak, oak-pine, and cloud forest; $n=4)$; and other (including urban $[n=2]$ and halophile vegetation $[n=1])$.

Table 1. Records of jaguarundi, reliability class of record, municipality and locality within municipality, and type of evidence (and provider for Class II records) of occurrences in San Luis Potosí, Mexico.

\begin{tabular}{c|c|c|c|c}
\hline Record & Class $^{\mathbf{1}}$ & Municipality & Locality & Evidence $^{\mathbf{2}}$ \\
\hline 1 & I & Lagunillas & Lagunillas & Pelt \\
\hline 2 & II & Tamuin & Rancho 'El Danes' & Observation (ranch worker) \\
\hline 3 & II & Tamuin & Rancho Zimapan Hidalgo & Observation (ranch worker) \\
\hline 5 & II & $\begin{array}{c}\text { San Vicente } \\
\text { Tancuayalab }\end{array}$ & Rancho 'El Cañaberal' & Observation (ranch worker) \\
\hline 6 & II & Tamuin & Rancho 16 & Observation (ranch owner) \\
\hline 7 & II & Tamasopo & San Nicolas de los Montes & Mounted specimen \\
\hline 8 & II & Zaragoza & Valle de los Fantasmas & Observation (ranch workers) \\
\hline 9 & II & Rio Verde & San Francisco & Observation (ranch workers) \\
\hline 10 & II & Rio Verde & Bordo Blanco & Observation (hunter) \\
\hline 11 & II & $\begin{array}{c}\text { San Nicolas } \\
\text { Tolentino }\end{array}$ & Las Milpitas & Description of thecies (ranch \\
\hline 12 & II & Rio Verde & Ejido San Francisco & Observations (hunter) \\
\hline 13 & II & Rio Verde & Los Peroles & Observation (ranch owner) \\
\hline 15 & I & San Ciro & Codornices y Capaderos & Pelt \\
\hline 16 & II & Rayon & Vaqueros & Observation (ranch workers) \\
\hline 17 & II & $\begin{array}{c}\text { San Martin } \\
\text { Chalchicuautla }\end{array}$ & $\begin{array}{c}\text { San Martin } \\
\text { owner) }\end{array}$ \\
\hline 28 & II & $\begin{array}{c}\text { San Martin } \\
\text { Chalchicuautla }\end{array}$ & Lagunillas & Obscription of the species (ranch \\
\hline 19 & II & $\begin{array}{c}\text { Tampacan } \\
\text { Carretera salinendo de } \\
\text { lagunillas }\end{array}$ & Observation (hunter) \\
\hline
\end{tabular}




\begin{tabular}{|c|c|c|c|c|}
\hline Record & Class $^{1}$ & Municipality & Locality & Evidence $^{2}$ \\
\hline 20 & II & Tanquian & Rancho 'Lagoleta' & Observation (ranch workers) \\
\hline 21 & II & Tanquian & El Capricho & $\begin{array}{c}\text { Description of the species (ranch } \\
\text { owner) }\end{array}$ \\
\hline 22 & II & Tampomolon & El Naranjo & Observation (hunter) \\
\hline 23 & II & Axtla de Terrazas & Arroyo de en medio & Observation (ranch worker) \\
\hline 24 & II & Xilitla & La Herradura & $\begin{array}{c}\text { Description of the species (ranch } \\
\text { owner) }\end{array}$ \\
\hline 25 & $\mathrm{I}$ & Cerritos & Joya de Luna & Mounted specimen \\
\hline 26 & II & Guadalcazar & Pozo de Acuña & Observation (ranch workers) \\
\hline 27 & II & Cd. Valles & La Antigua, Rancho Nuevo & $\begin{array}{c}\text { Description of species (ranch } \\
\text { worker) }\end{array}$ \\
\hline 28 & II & Cd. Valles & La Calera-Tamunal & Observation (ranch workers) \\
\hline 29 & II & Aquismon & Las Lajas & Observations (hunter) \\
\hline 30 & II & Aquismon & Tampate & Observation (ranch workers) \\
\hline 31 & II & Aquismon & La Caldera & Observation (ranch workers) \\
\hline 32 & II & Aquismon & El Naranjito & Observation (ranch workers) \\
\hline 33 & II & Cd. Valles & Las Granjas & $\begin{array}{c}\text { Description of the species (ranch } \\
\text { owner) }\end{array}$ \\
\hline 34 & II & Cd. Valles & Leon Garcia & Observation (hunter) \\
\hline 35 & II & Cd. Valles & Laguna de Mante & Observation (ranch workers) \\
\hline 36 & II & Cd. Valles & Los Sabinitos 2 & Observation (ranch workers) \\
\hline 37 & II & Cd. Valles & Las Pitas & $\begin{array}{c}\text { Description of species (ranch } \\
\text { workers) }\end{array}$ \\
\hline 38 & II & Tamuin & San Jose de limon & Observation (hunter) \\
\hline 39 & II & Ebano & Laguna Chica & Observation (ranch owner) \\
\hline 40 & II & Tamuin & Santa Martha & $\begin{array}{c}\text { Description of species (ranch } \\
\text { workers) }\end{array}$ \\
\hline 41 & I & Tamasopo & Tamasopo & Pelt \\
\hline 42 & II & Lagunillas & El Cañon & $\begin{array}{c}\text { Description of species (ranch } \\
\text { workers) }\end{array}$ \\
\hline 43 & II & Tamasopo & Cabezas & Observation (ranch workers) \\
\hline 44 & II & Tamasopo & Santa Maria & Observation (ranch owner) \\
\hline 45 & II & Cd. Valles & Cerro Alto & $\begin{array}{c}\text { Description of species (ranch } \\
\text { workers) }\end{array}$ \\
\hline 46 & II & El Naranjo & El Platanito & $\begin{array}{c}\text { Description of species (ranch } \\
\text { workers) }\end{array}$ \\
\hline 47 & II & Cd del Maíz & San Juan del Meco & Observation (ranch workers) \\
\hline 48 & II & $\begin{array}{l}\text { San Nicolas } \\
\text { Tolentino }\end{array}$ & Pozo del Aguila & Observation (ranch owner) \\
\hline 49 & II & $\begin{array}{l}\text { San Nicolas } \\
\text { Tolentino }\end{array}$ & Ojo de Agua & Observation (ranch owner) \\
\hline 50 & II & Tierra Nueva & La Joyita & Observation (ranch workers) \\
\hline
\end{tabular}

${ }^{1}$ Class I = observations made by a reliable interviewee supported by physical evidence; Class II = detailed description by a reliable and experienced observer (Tewes and Everett, 1986).

${ }^{2}$ Observation = individual had a priori knowledge of jaguarundi and knew that what they saw was a jaguarundi at time of observation; Description of species = observer was able to correctly describe the species to the interviewer, recognize it by a description given by the interviewer, and/or recognize it from a picture, without a priori knowledge of what a jaguarundi was.

Jaguarundi locations differed $\left(F_{11,10037}=17.2 ; P<0.001\right)$ from random points for most landscape attributes. Jaguarundi were located closer to water $\left(F_{1,10048}=15.3 ; P<0.001\right)$, closer to roads $\left(F_{1,10048}=\right.$ 17.4; $P<0.001)$, at lower elevation $\left(F_{1,10048}=71.6 ; P<0.001\right)$, and marginally closer to communities $\left(F_{1,10048}=3.5 ; P=0.061\right)$ than were random points. Human population density was similar $\left(F_{1,10048}=2.4 ; P\right.$ 
$=0.121$ ). Sixty-two percent of occurrences were $<500 \mathrm{~m}$ from water sources, $70 \%$ were $<500 \mathrm{~m}$ from roads, and $54 \%$ were $<500 \mathrm{~m}$ from the closest community or cluster of buildings. All occurrences were located below 2,000 $\mathrm{m}($ mean $=579 \mathrm{~m}$ [range $=16-1900])$ in elevation.

Jaguarundi locations also included more edge $\left(16.2 \mathrm{~km} \mathrm{v} .13 .6 \mathrm{~km} ; F_{1,10048}=4.2 ; P=0.041\right)$, greater edge density $\left(6.2\right.$ v. $\left.5.2 ; F_{1,10048}=4.2 ; P=0.041\right)$ and marginally more patches $\left(4.8\right.$ v. $4.3 ; F_{1,10048}=2.7 ; P$ $=0.100)$ than did random locations. Patch density $(0.18$ v. 0.16$)$, patch relative density $(0.11 \mathrm{v} .0 .11)$, and relative patch richness (18.6 v. 17.2) were $\operatorname{similar}\left(F_{1,10048}=2.4 ; P \geq 0.122\right)$.

Cover type also differed between jaguarundi locations and random points (Fisher's exact $P<0.001$ ); jaguarundi were found more frequently in tropical forest (Fisher's exact $P<0.001$ ) and agriculture (Fisher's exact $P<0.011$ ) cover types, and less frequently in desert scrub (Fisher's exact $P<0.001$ ). Jaguarundi presence was marginally positively related to urban (i.e., any mapped community regardless of type or size; Fisher's exact $P<0.066$ ) and grassland (Fisher's exact $P<0.071$ ) cover types as well. No other cover types differed (Fisher's exact $P \geq 0.287$ ) (Fig. 2).

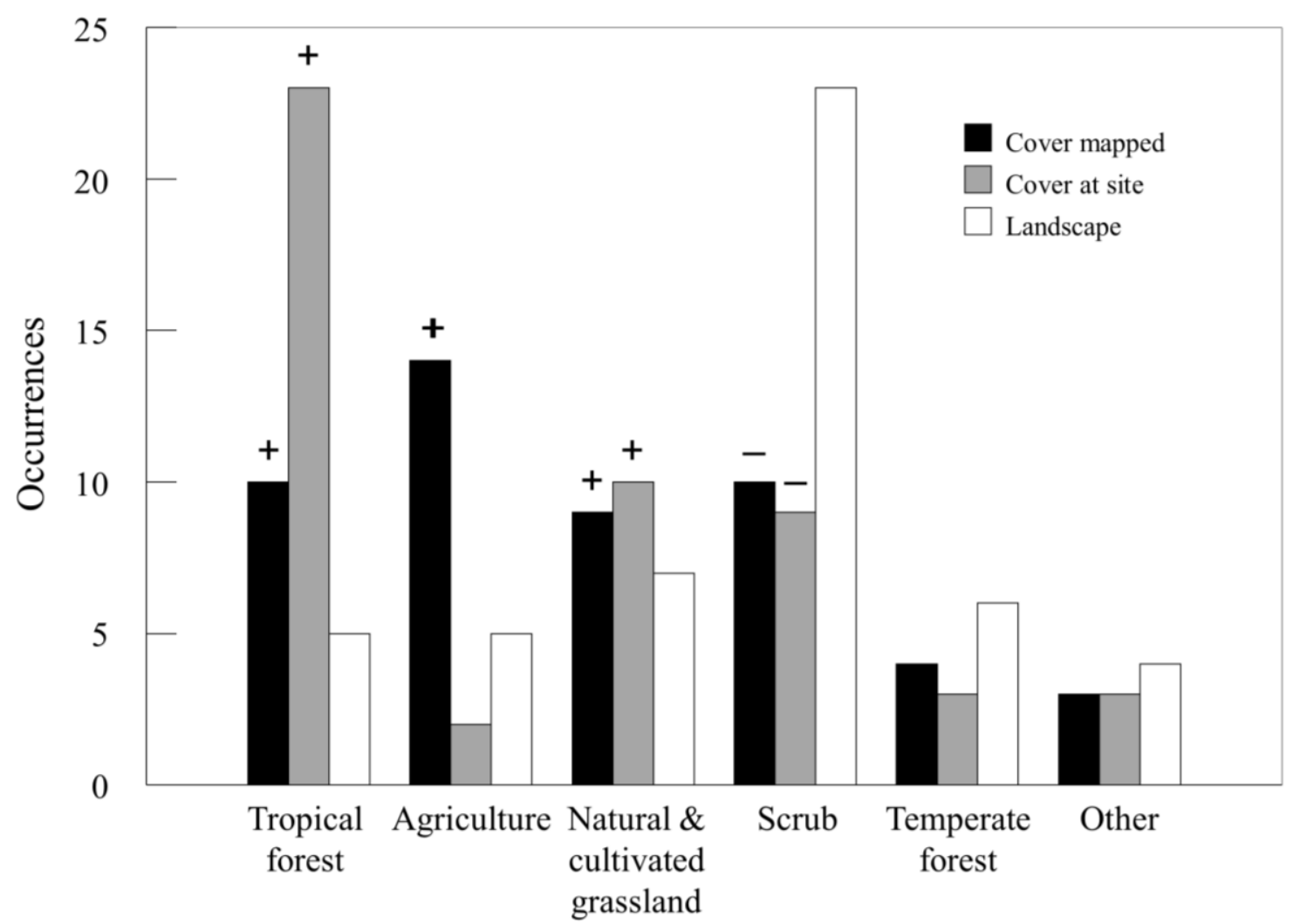

Figure 2. Vegetation cover-land use types associated with occurrences of jaguarundi at the actual site of occurrence (Cover at site), the general area as mapped on vegetation maps (Cover type mapped), and numbers expected based on proportional composition of the San Luis Potosí landscape (Landscape). Proportionately greater $(+)$ or lesser $(-)$ presence than expected $(\mathrm{P}<0.10)$ are noted above bars.

The logistical model including elevation + cover type + distance to roads $\left(\chi^{2}{ }_{3}=78.2 ; P<0.001\right.$; AUC $=0.912$; successful classification percentage $=90 \%$ ) was most strongly related to jaguarundi presence . Likelihood of jaguarundi presence was $>0.80$ in mosaics of tropical forest, agriculture, and urban cover types below $500 \mathrm{~m}$ in elevation within $1.5 \mathrm{~km}$ of a road (Fig. 3). Based on partial adjusted $\mathrm{R}^{2} \mathrm{~s}$, elevation 
(48\%) accounted for the most relative variance in model performance, followed by cover type (40\%) and distance to roads $(12 \%)$.

The maximum entropy model including cover type, elevation, distance to roads, and human population density provided the most parsimonious fit $(P \geq 0.907$ as compared to higher dimensioned, greater AUC models; $P \leq 0.081$ compared to lower dimensioned models) and fit data well (AUC $=0.909$; $\mathrm{SE}=0.027$; successful classification percentage $=88 \%)$. Model fit was also superior $(P=1.000)$ to 1,000 random null models. Elevation accounted for the most variance (36\%) in model performance, followed by cover type (25\%), distance to roads (23\%), and population density $(16 \%)$. Likelihood of presence of jaguarundi was $>0.80$ in mosaic agriculture-tropical forest, tropical forest-grassland, and tropical forest cover types (1) below $500 \mathrm{~m}$ in elevation, (2) $<2 \mathrm{~km}$ from roads, and (3) in areas with $>50$ but $<150$ people/km² (Fig. 4).

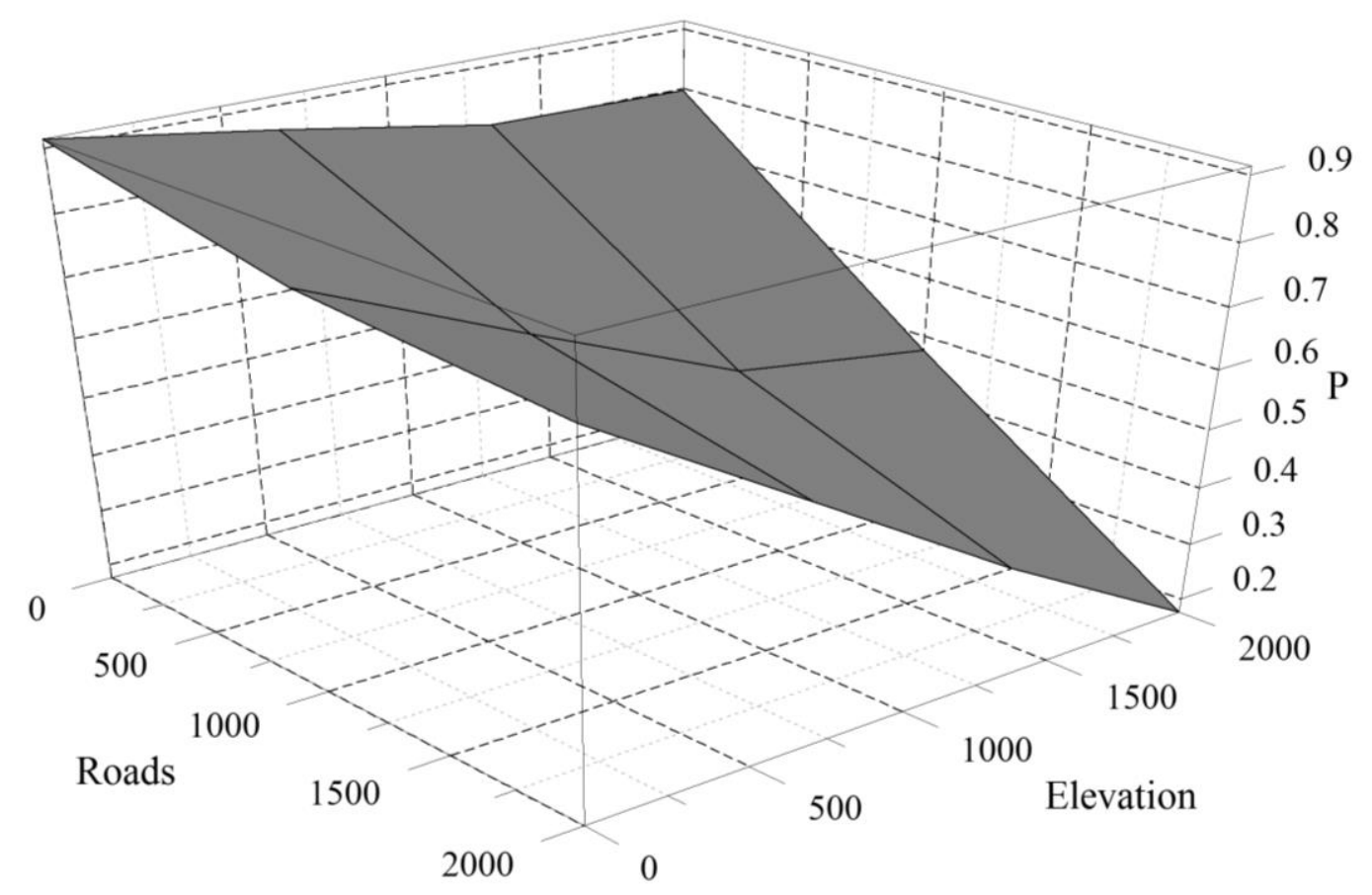

Figure 3. Mean likelihood of jaguarundi presence across preferred cover types (tropical forest, agriculture, grassland, and rural urban) as a function of distance from roads (m) and elevation (m).

The above models include identified mosaic associations with the individual cover types identified in the model selection procedures. For cover types identified as having high likelihood of jaguarundi occurrence by either model (i.e., tropical forest, agriculture, grassland, and urban), the predominant associated cover type was either the same cover type in a uniform neighborhood $32 \%$ of jaguarundi presence locations) or was a mosaic of tropical forest, agriculture, grassland, and/or urban (44\% of presence locations). Thus, tropical forest, agriculture, grassland, and urban were either the sole cover type or in mosaic in $76 \%$ of jaguarundi presence locations. In contrast, a uniform neighborhood of the cover type at the location was more common $(67 \%$; Fisher's exact $\mathrm{P}<0.001)$ for random locations on the SLP landscape. Last, model fit parameters were similar $(P \geq 0.749)$ between logistical and maximum entropy models (i.e., AUC $=0.912$ and 0.909 and successful classification percentage $=90 \%$ v. $88 \%$, respectively). Likelihood maps of jaguarundi presence were likewise strongly correlated $(I=0.90)$. 
Site characteristics. Locations of jaguarundi varied in ambush cover (Fisher's exact $P=0.023$ ); jaguarundi were seldom located in areas with very low ambush cover $(\mathrm{N}=2$ occurrences) as compared with areas of high $($ mean $=85.3 \% ; \mathrm{SE}=1.5 ; \mathrm{N}=19)$, medium (mean $=67.6 \% ; \mathrm{SE}=1.4 ; \mathrm{N}=13)$, and low cover $(39.3 \%$; $\mathrm{SE}=1.5 ; \mathrm{N}=16$ ), respectively. Jaguarundi were similarly (Fisher's exact $P=0.908$ ) located in areas that showed high (30\% of the records), medium (32\%), and low disturbance (38\%) of habitat.

Cover type at the site of occurrences varied compared to random locations (Fisher's exact $P<0.001$; Fig. 2). Jaguarundi were found more frequently in tropical forest (Fisher's exact $P<0.001$ ) and less frequently in desert scrub (Fisher's exact $P<0.001$ ) (Fig. 2). Jaguarundi were also found marginally more frequently in urban (Fisher's exact $P=0.066$ ) and submontane scrub (Fisher's exact $P<0.054$ ) cover types. No other cover types varied $(P \geq 0.159)$. When the actual occurrence was in tropical forest, agriculture, grassland, or urban cover types, the aspect dominant of the surrounding area was either the same cover type (17\% of occurrences) or was either tropical forest, agriculture, grassland, or urban (66\% of occurrences) if a different cover type. Thus, tropical forest, agriculture, grassland, and urban were either the sole cover type or in mosaic in $83 \%$ of jaguarundi occurrences, similar to mapped cover type results, above.

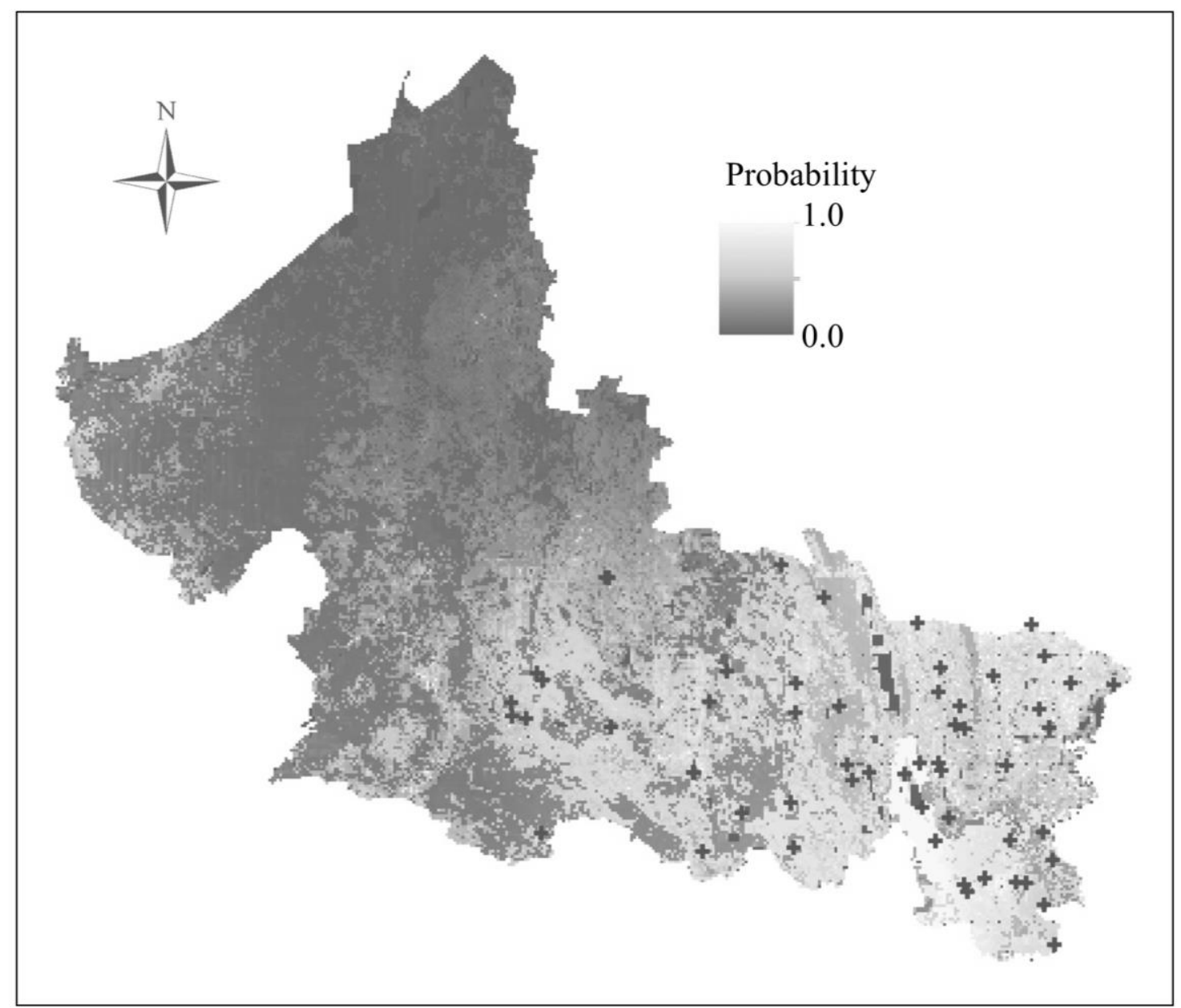

Figure 4. Likelihood of presence of jaguarundi in San Luis Potosí, Mexico, as predicted by maximum entropy modeling. Documented locations of jaguarundi are shown (+). 


\section{DISCUSSION}

Jaguarundi were commonly associated with human-altered habitats and were relatively widely distributed throughout the lower elevations of SLP (Fig. 4). These results supported previous work that indicated adaptability of jaguarundi with respect to cover types occupied and disturbance, including human-related disturbance (Caso, 1994, 2013; de Oliviera, 1998; Carrillo et al., 1999; Aranda, 2005; Peña-Mondragón, 2004; Giordano, 2016). Most of our occurrences were in cover types where jaguarundi have been previously recorded, including tropical forests, natural and cultivated grasslands, and oak forests (Guggisberg, 1975; Tewes \& Everett, 1986; de Oliveira, 1998; Brown \& González, 1999; Peña-Mondragón, 2004; CharréMedellín et al., 2012; Caso, 2013; Farías et al., 2015; Giordano, 2016). In addition to these, we also documented jaguarundi in several other cover types, including desert scrub and halophytic vegetation. Most relevantly, however, were the frequent locations in agriculture mosaics associated with the cover types noted above (especially tropical forest and grassland) and urban (i.e., communities) areas including communities of $>10,000$ inhabitants, highlighting the adaptability of jaguarundi to human-altered habitats.

Adaptability of jaguarundi to fragmented mosaic habitats in SLP resulting from human-related disturbance was evident in both landscape correlates and site characteristics of jaguarundi occurrences, i.e. primarily mosaics of tropical forest, agricultural sites (including irrigated agricultural fields, and seasonal croplands), and grasslands (including natural or cultivated pastures). Moreover, most occurrences were along induced edges associated with abrupt changes in land use or cover type, similar to habitat use patterns seen in north-eastern Mexico (Caso, 2013). Additionally, most jaguarundi occurrences were relatively close $(<500 \mathrm{~m})$ to water, roads, and communities, attributes which increase induced edge and thus likely presence and abundance of preferred prey (Aranda, 2005). Thus, jaguarundi may actually be benefitted by at least moderate human-induced fragmentation and habitat conversions, rather than merely being tolerant of these activities. Additional work on fitness (i.e., individual condition) and population-level productivity of jaguarundi in human-altered and natural communities is needed to determine to what extent jaguarundi may actually benefit from human-activities (sensu Baldwin \& Bender, 2009).

Our results thus support the adaptability of jaguarundi to at least moderate levels of human alterations of natural communities, as well as supporting likely preferences of jaguarundi for ecotones (Cabrera \& Yepes, 1960; Jiménez-Guzmán et al., 1997; Giordano, 2016), areas with secondary vegetation (Caso, 2013; Giordano, 2016), and tropical forest (Bisbal, 1989; Caso, 2013; Giordano, 2016), especially fragmented forests associated with agriculture or grassland. Because $>50 \%$ of jaguarundi occurrences were within $500 \mathrm{~m}$ of rural communities, rural human-associated fragmented habitats may provide highly favorable habitat conditions for jaguarundi, and likely their wild and domestic prey (Aranda, 2005; AriasAlzate et al., 2013). Adaptability of jaguarundi to human-altered habitats was further reflected in the significant associations of roads (logistical and maximum entropy models) and moderate human population density (maximum entropy model) with jaguarundi occurrences, as well as the greater total edge, edge density, and number of patches at actual locations as compared to random points. While we conducted surveys in or near rural communities, ejidos, and ranches, not all occurrences of jaguarundi were adjacent or close to communities, and were reflective of the SLP landscape. For example, distribution with respect to larger communities (i.e., urban areas [communities] included in the most recent cover type map of SLP [INEGI, 2013]) was relatively similar to the SLP landscape; random locations averaged $8 \mathrm{~km}$ from such communities, whereas jaguarundi occurrences averaged $7 \mathrm{~km}$, with $34 \%>8 \mathrm{~km}$ from the closest mapped community. Thus, our results provide not only documentation on the adaptability of jaguarundi to humanaltered habitats, but also reasonably reflect overall distribution and landscape level environmental correlates of jaguarundi in general. The exception to this may be that our results may underestimate jaguarundi tolerance of larger communities, as our sampling was biased towards rural landscapes.

Most agricultural and other human-altered habitats occur close to water and at low elevation, local attributes we also found associated with most occurrences of jaguarundi, reflecting other work in Mexico. 
For example, we found all occurrences at elevations $<1,900 \mathrm{~m}$, similar to Peña-Mondragón (2004) who found that the distribution of jaguarundi did not exceed elevations $>1,500 \mathrm{~m}$ in Nuevo Leon, Mexico. These results contrasted with those of Cuervo et al. (1986), who reported some individuals at $>3,200 \mathrm{~m}$ in elevation in Colombia. The distribution of jaguarundi in Mexico at lower elevations likely relates to increased humanrelated disturbance, and hence interspersed and edge habitats. Common disturbances associated with these landscapes include roads, narrow waterways (e.g., irrigation ditches), and rights-of-way, which are likely not barriers for jaguarundi movements (Campbell, 2003). Consequently, jaguarundi are generally considered more tolerant of human disturbances than are other threatened felids (Caso et al., 2015). While we did not find a significant relationship between site-level habitat disturbance as we categorized it and the presence of jaguarundi, landscape-level correlates and edge-related metrics support previous studies that showed jaguarundi to be tolerant of landscape disturbances associated with human activities, as long as sufficient low cover remained in those areas (Campbell, 2003; Caso, 2013; Giordano, 2016). Supporting this, we found most (64\%) jaguarundi occurrences were in the two densest ambush cover classes. Tewes and Schmidly (1987), Caso (1994) and Caso et al. (2015) noted that jaguarundi were able to inhabit more open terrain as long as it contained patches of structure that facilitated hiding and searching for prey. Thus, regardless of cover types occupied by jaguarundi, dense low cover is likely critical for jaguarundi presence, both to facilitate ambush of prey and to avoid detection by other larger predators. While little is known about jaguarundi prey preferences in Mexico, small rodents were recently identified as their primary prey in the Sierra del Abra Tanchipa Biosphere Reserve, located in northeastern San Luis Potosí (BenítezAlemán, 2014).

\section{CONCLUSIONS}

Reliable knowledge of the distribution of species-of-concern, and environmental attributes associated with its presence, is necessary for informed recovery plans. We found jaguarundi were relatively widely distributed in SLP, and were adaptable to and likely benefitted by at least moderate levels of human-related disturbance. This was evidenced by frequent locations in mosaic agricultural-natural vegetation landscapes that were relatively close to communities, especially lower elevations areas characterized by mosaics of forest (especially tropical forest), agriculture, and/or grasslands relatively close to water; as well as locations close to larger (i.e., >10,000 residents) urban centers. Natural resource managers should account for the adaptability of jaguarundi to human-altered habitats and consequently these environmental correlates in their conservation plans for the species in SLP and east-central Mexico. These associations and our likelihood mapping (Fig. 4) of jaguarundi presence provide a framework to identify key recovery areas and areas potentially important for connectivity among recovery areas to facilitate population viability. Relatedly, likelihood mapping also provides a tool to determine areas for more intensive surveying of jaguarundi presence, population demographics, and population status.

AKnOWledgements. We thank the Consejo Nacional de Ciencia y Tecnología (CONACYT), Mexico, for the scholarship provided to W. Coronado-Quibrera; the Secretaría de Desarrollo Agropecuario y Recursos Hidráulicos of San Luis Potosí, and the New Mexico State University Cooperative Extension Service for supporting this research. We also thank Jesús Martínez-Calderas and Gmelina Dueñas-López for their collaboration in this research, and all the people interviewed in this study for their willingness to share their knowledge.

\section{LITERATURE CITED}

Arnold, T. W. (2010) Uninformative parameters and model selection using Akaike's information criterion. Journal of Wildlife Management, 74, 1175-1178. 
Aranda, M. (2005) Herpailurus yagouaroundi. Pp: 358-359. In: G. Ceballos, G. Oliva (Eds.). Los Mamíferos Silvestres de México. CONABIO - Fondo de Cultura Económica, México D.F.

Arias-Alzate, A., Delgado, C. A., Ortega, J. C., Botero-Canola, S., Sanchez-Londono, J. D. (2013) Presencia de Puma yagouaroundi (Carnivora: Felidae) en el Valle de Aburrá, Antioquia, Colombia. Brenesia, 79, 83-84.

Baldwin, R. A., Bender, L. C. (2008) Den-site characteristics of black bears in Rocky Mountain National Park, Colorado. Journal of Wildlife Management, 72, 1717-1724.

Baldwin, R. A., Bender, L. C. (2009) Survival, productivity, and trends of a low density black bear population in Rocky Mountain National Park, Colorado. Human-Wildlife Conflicts, 3, 271-281.

Bender, L. C., Rosas-Rosas, O. C., Weisenberger, M. E. (2017) Seasonal occupancy of sympatric larger carnivores in the southern San Andres Mountains, south-central New Mexico, USA. Mammal Research, 62, 323-329.

Benítez-Alemán, H. E. (2014) Identificación molecular de heces y análisis de hábitos alimenticios de carnívoros en la Reserva de la Biósfera Sierra del Abra Tachipa, San Luis Potosí, México. Tesis de maestría, Colegio de Postgraduados, Texcoco, México.

Bisbal, F. J. (1989) Food habits of some neotropical carnivores in Venezuela (Mammalia, Carnivora). Mammalia, 50, 329-339.

Brown, D. E., González, C. A. (1999) Jaguarundi (Herpailurus yagouaroundi Geoffroy 1803) not in Arizona or Sonora. Journal of Arizona-Nevada Academy of Science, 32, 155-157.

Cabrera, A., Yepes, J. (1960) Mamíferos Sudamericanos: vida, costumbres y descripción. Historia Natural Ediar. Companhia Argentina de editores, Buenos Aires.

Campbell, L. (2003) Endangered and threatened animals of Texas: Their life history and management. Texas Parks and Wildlife Department, Austin.

Carrillo, E., Grace, W., Saenz, J. C. (1999) Mamíferos de Costa Rica. INBIO, Santo Domingo, Costa Rica.

Carrol, C., Miquelle, D. (2006) Spatial viability analysis of Amur tiger Panthera tigris altaica in the Russian Far East: the role of protected areas and landscape matrix in population persistence. Journal of Applied Ecology, 43, 1056-1068.

Caso, A. (1994) Home range and habitat use of three Neotropical carnivores in northeast México. M.Sc. thesis, Texas A\&M University, Kingsville.

Caso, A. (2013) Spatial differences and local avoidance of ocelot (Leopardus pardalis) and jaguarundi (Puma yagouaroundi) in northeast Mexico. Ph.D. thesis, Texas A\&M University, Kingsville.

Caso, A., de Oliveira, T., Carvajal, S. V. (2015) Herpailurus yagouaroundi. The IUCN Red List of Threatened Species 2015: e.T9948A50653167. Available at: http://dx.doi.org/10.2305/IUCN.UK.2015-2.RLTS.T9948A50653167.en

Chapa-Vargas, L., Monzalvo-Santos, K. (2012) Natural protected areas of San Luis Potosí, Mexico: ecological representativeness, risks, and conservation implications across scales. International Journal of Geographical Information Science, 26, 1625-1641.

Charre-Medellín, J. F., Sánchez-Cordero, V., Magaña-Cota, G., Álvarez-Jara, M., Botello, F. (2012) Jaguarundi (Puma yagouaroundi) in Guanajuato, Mexico. The Southwestern Naturalist, 57, 117118.

Cuervo, A., Hernández, J., Cadena, A. (1986) Lista actualizada de los mamíferos de Colombia: Anotaciones sobre su distribución. Caldasia, 15, 471-501.

Dalquest, W. W. (1953) Mammals of the Mexican state of San Luis Potosí. Biological Sciences Series 1: 1-229, Louisiana State University, Baton Rouge.

de Oliveira, T. G. (1994) Neotropical cats: ecology and conservation. EDUFMA, Sao Luis MA, Brasil.

de Oliveira, T. G. (1998) Herpailurus yagouaroundi. Mammalian Species, 578, 1-6.

Dillon, A. (2005) Ocelot density and home range in Belize, Central America: camera-trapping and radio telemetry. M.Sc. Thesis, Virginia Polytechnic Institute and State University, Blacksburg. 
Escalante, T., Rodríguez, G., Morrone, J. J. (2005) Las provincias biogeografías del componente mexicano de montaña desde la perspectiva de los mamíferos continentales. Revista Mexicana de Biodiversidad, 76, 199-205.

Efron, B., Tibshirani, R. J. (1993) An introduction to the bootstrap. Chapman \& Hall, New York.

Fielding, A. H., Bell, J. F. (1997) A review of methods for the assessment of prediction errors in conservation presence/absence models. Environmental Conservation, 24, 38-49.

Farías, V., Téllez, O., Botello, F., Hernández, O., Berruecos, J., Olivares, S. J., Hernández, J. C. (2015) Primeros registros de 4 especies de felinos en el sur de Puebla, México. Revista Mexicana de Biodiversidad, 86, 1065-71.

Giordano, A. J. (2016) Ecology and status of the jaguarundi Puma yagouaroundi: a synthesis of existing knowledge. Mammal Review, 46, 30-43.

GlobCover

Available

at: http://www.esa.int/Our_Activities/Observing_the_Earth/Space_for_our_climate/ESA_global_land _cover_map_available_online

Griffith, B., Youtie, B. A. (1988) Two devices for estimating foliage density and deer hiding cover. Wildlife Society Bulletin, 16, 206-210.

Grigione, M., Scoville, A., Scoville, G., Crooks, K. (2007) Neotropical cats in southeast Arizona and surrounding areas: past and present status of jaguars, ocelots and jaguarundis. Mastozoología Neotropical, 14, 189-199.

Guggisberg, C. A. W. (1975) Wild cats of the world. Taplinger, New York.

Hall, E. R. (1981) The mammals of North America, Vol 2. John Wiley \& Sons, New York.

Hernández-SaintMartín, A. D., Rosas-Rosas, O. C., Palacio-Núñez, J., Tarango-Arámbula, L. A., Clemente-Sánchez, F., Hoogesteijn, A. L. (2013) Activity patterns of jaguar, puma and their potential prey in San Luis Potosí, Mexico. Acta Zoológica Mexicana (nueva serie), 29, 520-533.

Horne, J. S., Haines, A. M., Tewes, M. C., Laack, L. L. (2009) Habitat partitioning by sympatric ocelots and bobcats: implications for recovery of ocelots in Southern Texas. Southwestern Naturalist, 42, 119-126.

Hosmer, D., Lemeshow, S. (1989) Applied logistic regression. J. Wiley \& Sons, New York.

Huber-Sannwald, E. (2002) Land use change - a local or global issue? Primer foro ambiental del Departamento de Ingeniería Ambiental y Manejo de Recursos Naturales. Reportes del Instituto Potosino de Investigación Científica y Tecnológica, 1, 110-117.

INEGI (2002) Síntesis de Información Geográfica del Estado de San Luis Potosí. Instituto Nacional de Geografía e Informática, Aguascalientes, México.

INEGI (2013) Conjunto de datos vectoriales de uso de suelo y vegetación escala 1:250 000, serie V (capa unión), escala: 1:250000. Edición: 2a. Instituto Nacional de Estadística y Geografía, Aguascalientes, México. Available at: http://www.conabio.gob.mx/informacion/gis/?vns=gis_root/usv/inegi/usv250s5ugw

Jiménez-Guzmán, A., Zúñiga-Ramos, M. A., Niño-Ramírez, J. A. (1997) Lista anotada de mamíferos de Nuevo León, México. Revista Mexicana de Mastozoología, 2, 132-141.

Leopold, A. S. (1959) Fauna silvestre de México. University of California Press, Berkeley.

Martínez-Calderas, J. M. (2009) Nuevos registros y distribución del ocelote (Leopardus pardalis) en el noreste de México. Tesis de Maestría, Colegio de Postgraduados, Campus Montecillo, Texcoco, México.

Martínez-Calderas, J. M., Rosas-Rosas, O. C., Martínez-Montoya, J. F., Tarango-Arámbula, L. A., Clemente-Sánchez, F., Crosby-Galván, M. M., Sánchez-Hermosillo, M. D. (2011) Distribución del ocelote (Leopardus pardalis) en San Luis Potosí, México. Revista Mexicana de Biodiversidad, 82, 997-1004.

Méndez-Salinas, E. (2009) Riqueza de Carnívoros en el Ejido San Nicolás de los Montes, Tamasopo, SLP. Tesis de Licenciatura, Facultad de Ciencias Biológicas, UANL, Monterrey, México.

Morrison, D. F. (1990) Multivariate statistical methods. McGraw Hill, New York. 
Ochoa-Ochoa, L., Urbina-Cardona, J. N., Vázquez, L. -B., Flores-Villela, O., Bezaury-Creel, J. (2009) The effects of governmental protected areas and social initiatives for land protection on the conservation of Mexican amphibians. PLoS ONE, 4 (9), e6878.

Pearce, J., Ferrier, S. (2000) Evaluating the predictive performance of habitat models developed using logistic regression. Ecological Modelling, 133, 225-245.

Peña-Mondragón, J. L. (2004) Distribución de jaguarundi (Herpailurus yagouaroundi cacomitli, Lacepede 1809) en el Estado de Nuevo León, México. Tesis de Licenciatura, Facultad de Ciencias Biológicas, Universidad Autónoma de Nuevo León, México.

Philips, S. J., Anderson, R. P., Shapire, R. E. (2006) Maximum entropy modeling of species geographic distributions. Ecological Modelling, 190, 231-259.

Primack, R. B. (1993) Essentials of conservation biology. Sinauer, Sunderland, MA.

Raes, N., ter Steege, H. (2007) A null-model for significance testing of presence-only species distribution models. Ecography, 30, 727-736.

Rabinowitz, A. R. (1993) Wildlife field research and conservation training manual. Wildlife Conservation Society, New York.

Rempel, R. S., Kaukinen, D., Karr, A. P. (2012) Patch analyst and patch grid. Ontario Ministry of Natural Resources, Center for Northern Forests Ecosystem Research, Thunder Bay.

Rzedowski, J. (1966) Vegetación del estado de San Luis Potosí. Acta Científica Potosina, 5, 5-291.

SEMARNAT (2010) Norma Oficial Mexicana (Nom-059-Ecol-2001). Protección ambiental-Especies nativas de México de flora y fauna silvestres-Categorías de riesgo y especificaciones para su inclusión, exclusión o cambio-Lista de especies en riesgo. Diario oficial de la federación, 30 de diciembre de 2010.

Shindle, O. P., Tewes, M. E. (1998) Woody spears composition of habitat used by ocelots (Leopardus pardalis) in the Tamaulipan biotic province. Southwestern Naturalist, 43, 274-278.

Swets, J. A. (1988) Measuring the accuracy of diagnostic systems. Science, 240, 1285-1293.

Tewes, M. E., Everett, D. D. (1986) Status and distribution of the endangered ocelot and jaguarundi in Texas. Pp: 147-148. In: S. D., Miller, D. D., Everett (Eds.). Cats of the world: biology, conservation and management. National Wildlife Federation, Washington D.C.

Tewes, M. E., Schmidly, D. J. (1987) The neotropical felids: jaguar, ocelot, margay and jaguarundi. Pp: 697-711. In: M. Novak, J. A. Baker, M. E. Obbard, B. Malloch (Eds.). Wild furbearer management and conservation in North America. Ontario Ministry of Natural Resources, Toronto.

Trisurat, Y., Bhumpakphan, N. (2018) Effects of land use and climate change on Siamese Eld's deer (Rucervus eldii siamensis) distribution in the Transboundary Conservation Area in Thailand, Cambodia, and Lao. Frontiers in Environmental Science, 6, 35.

Villordo-Galván, J. A., Rosas-Rosas, O. C., Clemente-Sánchez, F., Martínez-Montoya, J. F., TarangoArámbula, L. A., Mendoza-Martínez, G., Sánchez-Hermosillo, M. D., Bender, L. C. (2010) The jaguar (Panthera onca) in San Luis Potosí, Mexico. Southwestern Naturalist, 55, 394-402.

Warren, D. L., Glor, R. E., Turelli, M. (2008) Environmental niche equivalency versus conservatism: quantitative approaches to niche evolution. Evolution, 62, 2868-2883.

Zar, J. H. (1996) Biostatistical analysis. Prentice Hall, Upper Saddle River, NJ. 